\title{
New breeding locality for Crowned Cormorant
}

\section{P.A. WhitTington}

The Crowned Cormorant Phalacrocorax coronatus is endemic to the southern African subregion with an estimated population of about 2700 pairs, breeding at 48 localities between Walvis Bay, Namibia and Cape Agulhas, South Africa (Crawford et al. 1994, Crawford 1997). The easternmost point at which breeding has previously been recorded is $2 \mathrm{~km}$ west of Aasfontein $\left(34^{\circ} 46^{\prime} \mathrm{S}\right.$, $19^{\circ} 50^{\prime} \mathrm{E}$ ), where 35 nests were recorded in January 1981 (Crawford et al. 1982). Non-breeding birds have been seen further to the east as far as Holkom Meester se Baai $\left(34^{\circ} 23^{\prime} \mathrm{S}, 2^{\circ} 49^{\prime} \mathrm{E}\right)$ (Crawford et al. 1982).

On 29 October 2003, counts were made of breeding seabirds at the Number 12 Stacks (33⒌'S, $\left.23^{\circ} 35^{\prime} \mathrm{E}\right)$ in the De Vasselot section of the Tsitsikamma National Park. Counts were made of occupied nests and fledged young of all species present on three stacks visible from the mainland. These three stacks were thought to be those labelled as Carbo, Capensis and Dominicanus by Crawford (1983).

While counting nests of White-breasted Cormorants Phalacrocorax carbo lucidus and Cape Cormorants Phalacrocorax capensis, four occupied nests of Crowned Cormorants were located on the stack corresponding to that named Carbo by Crawford (1983). All four had a sitting bird and it was not possible to see whether the nests contained eggs or chicks. Most occupied nests of nearby White-breasted and Cape Cormorants contained chicks. In addition, 20 fledged White-breasted Cormorants and 71 fledged Cape
Cormorant chicks were counted on this stack (Table 1). The solitary Little Egret Egretta

Table 1

Counts of occupied nests, old nests and fledged young of all species breeding at Number 12 Stacks, 29 October 2003

\begin{tabular}{ccc}
\hline Sarbo & Capensis & $\begin{array}{c}\text { Domini- } \\
\text { canus }\end{array}$ \\
\hline
\end{tabular}

\section{White-breasted}

\section{Cormorant}

Phalacrocorax carbo

Occupied nests (total)

Nests with chicks visible 6

Old nests

Fledged young

15
6
13
20

15

20

Cape Cormorant

Phalacrocorax capensis

Occupied nests (total)

Nests with chicks visible

Old nests

27
25
not
counted
71

$\begin{array}{cc}2 & 8 \\ 0 & 6 \\ \text { not } & \text { not } \\ \text { counted } & \text { counted } \\ 103 & 94\end{array}$

Fledged young

\section{Crowned Cormorant}

Phalacrocorax coronatus

Occupied nests (total)

Nests with chicks visible

Old nests

Fledged young

$\begin{array}{lll}4 & 0 & 0 \\ 0 & 0 & 0 \\ 0 & 0 & 0 \\ 0 & 0 & 0\end{array}$

\section{Little Egret}

Egretta garzetta

Occupied nests (total)

Nests with chicks visible 0

Old nests

Fledged young

$\begin{array}{ll}0 & 0 \\ 0 & 0 \\ 0 & 0 \\ 0 & 0\end{array}$

\section{Kelp Gull}

Larus dominicanus

\begin{tabular}{llll} 
Occupied nests (total) & 1 & 11 & 5 \\
Nests with chicks visible & 0 & 0 & 0 \\
Old nests & 0 & 0 & 0 \\
Fledged young & 0 & 0 & 0 \\
\hline
\end{tabular}


garzetta nest contained one egg.

Crowned Cormorants can breed throughout the year (Rand 1960). At Malgas Island off the west coast of South Africa, most breeding takes place between September and April with a peak in breeding activity between December and March (Crawford et al. 1999). It is thought that the birds recorded at Number 12 stacks were either incubating eggs or brooding small chicks.

The potential for the Crowned Cormorant to extend its breeding range on finding suitable breeding sites is illustrated by the construction of the Bird Rock Platform north of Walvis Bay, Namibia, and the wreck of the Meisho Maru No. 8. These resulted in previous breeding range extensions of $415 \mathrm{~km}$ to the north and $16 \mathrm{~km}$ to the east respectively (Crawford et al. 1994). This observation extends the breeding range of the Crowned Cormorant by approximately $355 \mathrm{~km}$ to the east and is about $169 \mathrm{~km}$ east of the nearest observations made of non-breeding birds. The species was not recorded by previous seabird surveys made in Tsitsikamma National Park (Crawford 1983).

\section{Acknowledgements}

Support for this research from the University of Port Elizabeth and from the National Research Foundation is gratefully acknowledged. I am indebted to Andre Riley of South African National Parks for arranging access to seabird colonies within Tsitsikamma National Park at very short notice, to Karools Peterse for guidance in the field and to Peter and Carol Humphrey for their wonderful hospitality.
R.J.M. Crawford, John Cooper and N.T.W. Klages commented on the draft manuscript.

\section{References}

CRAWFORD, R.J.M. 1983. Some observations on seabirds breeding in the Tsitsikamma Coastal National Park. Koedoe 26: 145-152.

Crawford, R.J.M. 1997. Crowned Cormorant Phalacrocorax coronatus. Pp 38-39. In: HARRISON, J.A., D.G. Allan, L.G. Underhill, M. Herremans, A.J. Tree, V. Parker \& C.J. Brown. (eds.). The atlas of southern African birds. Vol 1. Non-passerines. Johannesburg: BirdLife South Africa.

Crawford, R.J.M., P.A. Shelton, R.K. Brooke \& J. COOPER. 1982. Taxonomy, distribution, population size and conservation of the Crowned Cormorant, Phalacrocorax coronatus. Le Gerfaut 72: 3-30.

Crawford, R.J.M., B.M. Dyer \& R.K. Brooke. 1994. Breeding nomadism in southern African seabirds-constraints, causes and conservation. Ostrich 65: 231-246.

Crawford, R.J.M., B.M. Dyer \& L. Upfold. 1999. Seasonal pattern of breeding by Cape and Crowned Cormorants off western South Africa. Ostrich 70(3\&4): 193-195.

RAND, R.W. 1960. Biology of guano-producing seabirds 3. Distribution, abundance and feeding habits of the cormorants Phalacrocoracidae off the south western coast of the Cape Province. Investigational Report Department of Commerce and Industries, Division of Sea Fisheries. 42: 1-32.

\section{P.A. WhitTington,}

Department of Zoology, University of Port Elizabeth, Box 1600, Port Elizabeth, 6000, South Africa (philip.whittington@upe.ac.za) 